\title{
Hur får man en högskolepedagogisk satsning att leva vidare? Några reflektioner kring ämnesintegrering av akademiskt skrivande på Polisutbildningen
}

\author{
Hedda Söderlundh ${ }^{*, a}$, Therese Lind ${ }^{\mathrm{b}}$, Anders Nordström ${ }^{\mathrm{c}}$ \\ ä̈dertörns högskola, Institutionen för kultur och lärande; ${ }^{b}$ Södertörns högskolebibliotek; 'Södertörns \\ högskola, Polisutbildningen
}

\begin{abstract}
Den här texten handlar om ett högskolepedagogiskt samarbete som syftat till att skapa en ämnesintegrerad introduktion i akademiskt skrivande för polisstudenter vid Södertörns högskola. I texten beskrivs hur samarbetet har sett ut och vad som har fått introduktionen att leva kvar i programmet. Vi diskuterar utmaningar som uppstått och avslutar med några råd till den som vill genomföra liknande satsningar och samarbeten.
\end{abstract}

Nyckelord: Högskolepedagogisk utveckling, akademisk litteracitet, ämnesintegrering, polisutbildning

\section{ÄMNESINTEGRERAT AKADEMISKT SKRIVANDE}

Svenska lärosäten arbetar med att stödja studenters akademiska skrivande - att söka, värdera, läsa och skriva akademiska texter - på en mängd olika sätt. Ofta erbjuder språk- och studieverkstäder tillsammans med lärosätets bibliotek undervisning och handledning kring skriv- och sökstrategier, även om det också finns exempel på ämnesintegrerat stöd till utbildningar (se t.ex. Lennartson-Hokkanen, 20I6). I denna text berättar vi om ett exempel av det senare slaget från Södertörns högskola där ett samarbete mellan å ena sidan Utvecklingsenheten för högskolepedagogik och bildning, Biblioteket samt Studieverkstan, å andra sidan högskolans olika utbildningar, har genomförts under flera års tid. ${ }^{I}$ Fokus här ligger vid akademiskt skrivande inom Polisutbildningen² och vad som fătt satsningen att leva kvar inom programmet efter att

1 Samarbetet har beskrivits tidigare i bl.a. Högre utbildning (se Eklund Heinonen \& Sköldvall, 2015) och studenternas upplevelser har återgetts i Sköldvall, Rising och Danielsson 20I7. Denna text tar vid där de tidigare slutar och kan med fördel läsas efter de andra. Vi vill rikta ett tack till Kajsa Sköldvall, som representerat Studieverkstan i samarbetet, och som bidragit med värdefulla kommentarer till denna text.

2 Delkursen heter Polisen i samhället och ligger i period I under Polisutbildningens första termin. Syftet är att ge studenterna en grund i demokratifrågor och mänskliga rättigheter. Delkursen lästes senast VTı7 av 220 studenter och involverade nio lärare.

\footnotetext{
* Författarkontakt: Hedda Söderlundh, hedda.soderlundh@sh.se

Artiklar och reflektioner är kollegialt granskade. Övriga bidragstyper granskas av redaktionen. Se www.hogreutbildning.se ISSN 2000-7558

(C)2017 Hedda Söderlundh et al. This is an Open Access article distributed under the terms of the Creative Commons Attribution-NonCommercial 4.0 International License (https://creativecommons.org/licenses/by-nc/4.0/), allowing third parties to share their work (copy, distribute, transmit) and to adapt it, under the condition that the authors are given credit, that the work is not used for commercial purposes, and that in the event of reuse or distribution, the terms of this license are made clear.

Citation: Hedda Söderlundh et al. (2017) «Hur fär man en högskolepedagogisk satsning att leva vidare? Nägra reflektioner kring ämnesintegrering av akademiskt skrivande på Polisutbildningen", Högre utbildning 7(2), 35-39. http://dx.doi.org/10.23865/hu.v7.1035
} 
samarbetet avslutats. Vi som har skrivit texten representerar parterna i samarbetet ${ }^{3}$ och vår förhoppning är att våra erfarenheter kan komma till nytta särskilt för studieverkstäder och bibliotek som vill stötta lärares arbete med studenters akademiska skrivande.

\section{SAMARBETETS UTGÅNGSPUNKTER OCH UPPLÄGG}

Samarbetet startade 20I3 och har hittills genomförts med I6 ämnen eller program, varav Polisutbildningen är ett. Målet är framför allt högskolepedagogiskt: genom samarbetet ska utbildningens lärare få inspiration och verktyg att utveckla studenternas färdigheter i akademiskt skrivande. Det högskolepedagogiska målet är i sin tur knutet till det teoretiska perspektiv som präglar fälten $a k a-$ demisk litteracitet (Lea \& Street, 1998) och informationskompetens (se t.ex. Saunders, 20I2). Där betonas att skriv- och sökfärdigheter är del av det sociala sammanhang som ett ämne eller en vetenskaplig disciplin utgör och att språkbruket i högsta grad är del av ämnets kunskapskonstruktion. Som en del av detta uppmärksammas att det inte sällan finns skillnader mellan ämnen och discipliner ifråga om ideal och förväntningar, t.ex. hur tidigare forskning bör refereras eller vilket utrymme den egna rösten ska ges i relation till tidigare studier. Betonandet av ett ämnesspecifikt skrivande ger lärarna en nyckelroll för studenternas akademiska litteracitetsutveckling. Generella råd om akademiskt skrivande kan inte möta studenternas behov i samma grad, eftersom råden är frikopplade från det sociala sammanhang som ämnet utgör (Lea \& Street, I998).

Basen i samarbetet på Södertörn består av att Studieverkstan och Biblioteket genomför ett moment i den aktuella utbildningen, vilket planeras tillsammans med delkursens lärare och anpassas efter delkursens innehåll och mål. I stora drag innehåller momentet ett första seminarium om genrer, stildrag och informationssökning, en individuell skriv- och sökuppgift där studenterna ska referera såväl kurslitteratur som en egen vald vetenskaplig artikel, samt ett andra seminarium som kretsar kring ett första utkast av studenternas skriv- och sökuppgift. ${ }^{4}$ Samarbetet pågår i tre terminer, vilket också varit fallet med Polisutbildningen. Under den första och andra terminen genomförs momentet av Studieverkstan och Biblioteket, med stöd från utbildningens lärare. Under den tredje terminen håller utbildningens lärare i momentet, men med stöd från Studieverkstan och Biblioteket. Efter den tredje terminen lämnas momentet över till utbildningen och samarbetet avslutas. Särskilt i början av, men också under samarbetet, har lärarna kontakt med den högskolepedagogiska enheten.

Överlämningen till olika utbildningar har inte alltid varit enkel. Det har bl.a. varit svårt att finna tid och rutiner för hur lärarna kan ta över arbetet. Vissa lärare rapporterar att det varit svårt att hinna med momentet, medan andra gett uttryck för osäkerhet - eller ointresse - inför att undervisa om akademiskt skrivande. I ett par fall har momentet inte alls levt kvar efter den tredje terminen och ofta har det berott på att de lärare som ingått i samarbetet inte varit fast anställda, eller att de från en termin till en annan fått ansvar för nya kurser. Vid enstaka tillfällen har lärarna efter samarbetet frågat om momentet kan köpas - vilket måste ses som ett misslyckande i relation till lärarnas betydelse för att förmedla ämnesspecifika skriv- och söknormer. Överlämningen till Polisutbildningen kan dock sägas vara ett ovanligt lyckat exempel, eftersom momentet lever kvar i en integrerad form samtidigt som lärarna upplever att kvaliteten i studentuppgifterna ökat.

3 Hedda Söderlundh är lektor i svenska och har i samarbetet representerat den högskolepedagogiska enheten. Therese Lind är bibliotekarie med särskilt uppdrag som pedagogisk samordnare. Anders Nordström är lektor i statsvetenskap och delkursansvarig lärare på Polisen i samhället.

4 För en detaljerad beskrivning av hur momentet sett ut på Polisutbildningen, se Sköldvall, Rising och Danielsson 2017. 
Som Sköldvall, Rising och Danielsson (20I7) beskriver uppger även många polisstudenter att momentet varit lärorikt och att det gett både konkreta verktyg och ökad insikt om den akademiska sök- och skrivprocessen (s. 225ff). Från högskolepedagogiskt håll har också det akademiska litteracitetsperspektivet förstärkts under åren: samarbetet innehåller numera en inledande workshop för alla lärare i kollegiet om ämnesintegrerat skrivande och lärarna förväntas själva genomföra momentet den tredje terminen, vilket inte var ett krav från början.

\section{INTEGRERING OCH ÖVERLÄMNING AV MOMENTET}

När samarbetet med Polisutbildningen inleddes var programmet i en uppbyggnadsfas och präglades av ett slags nybyggaranda. Efter den första terminens samarbete fanns en förväntan och förhoppning inför fortsättningen från ledningen, men också från lärarna i de efterföljande delkurserna. Studenternas skrivande var prioriterat och den akademiska ledaren för utbildningen gav den delkursansvariga läraren för Polisen i samhället (hädanefter Anders) i uppdrag att integrera strimman om akademiskt skrivande i delkursen. Att det fanns ett uttalat uppdrag tror vi är en, av flera, anledningar till att momentet levt kvar.

Inför den andra terminen anpassades momentet ytterligare efter delkursens innehåll, bl.a. genom att skriv- och sökuppgiften reviderades och studiemanualen sågs över. Anders flyttade också över formkraven för den individuella uppgiften till andra gruppuppgifter i kursen, så att det blev en enhetlighet inom delkursen. Samtidigt gavs den individuella uppgiften större vikt genom att den blev avgörande för betyget VG. Färdigheter i akademiskt skrivande lades också till i kursplanen som ett eget lärandemål, vilket gjorde att momentet rent formellt fick större betydelse.

Inför den tredje och sista terminen bjöds alla lärare på Polisutbildningen in till ett möte med Studieverkstan och Biblioteket. Vidare tog bibliotekarien Therese tillsammans med Anders fram en ny responsmall för referenser, som både studenter och lärare kunde använda sig av, och Anders skapade betygskriterier för den individuella uppgiften. Följande begrepp och angreppssätt blev till slut särskilt viktiga i undervisning, respons och betygskriterier: vetenskaplig text, genrer, tredelad textstruktur (inledning, huvuddel, avslutning), självbärande text, referatmarkör samt röst (egen röst och de röster som refereras). Som bl.a. Eklund Heinonen och Sköldvall (20I5) tidigare konstaterat är fördelen med att lyfta fram ett antal begrepp att studenter och lärare får ett gemensamt språk, vilket också skedde här. Anders vittnar t.ex. om hur man genom terminologin får något att ta spjärn emot i diskussioner med kollegor och studenter, vilket underlättar i såväl betygssättning som vid ev. samtal med studenter om krav på komplettering.

\section{UTMANINGAR}

Den största utmaningen med att få ett moment av detta slag att leva kvar är antagligen att ett relativt väloljat moment, som inbegriper finansierat stöd från ett antal skrivlärare och bibliotekarier, ska tas över av en utbildning och inlemmas i en delkurs med dess ordinarie resurser. Uppenbarligen krävs det engagemang och tid från den delkursansvariga, bl.a. ifråga om att involvera och engagera de andra lärarna. För lärarlaget handlar det också om att skapa samsyn, t.ex. vad gäller hur strikt man ska vara i bedömningen av formalia i studentuppgifterna. Anders träffar numera lärarlaget före, under och efter delkursen för att samordna upplägget och han har skrivit en lärarhandledning för nya lärare.

En annan svårighet som kom fram redan under den första terminen var att studenterna vittnade om en hög stress när de fick den individuella uppgiften. Studenterna uppfattade det som att 
högskolan redan från första veckan kom med andra krav än vad de förväntat sig; istället för att utbildas i praktisk poliskunskap skulle de skriva akademisk text med särskilda formkrav. En student med bakgrund inom boxning beskrev det som att kastas in i ringen mot en okänd motståndare som man måste besegra - men med ben och armar uppbundna. För lärarna innebar denna stress att studenterna ställde högre krav än tidigare på respons och stöd, och lärarna fick ta emot kritik när de inte kunde lägga den tid på responsarbete som studenterna önskade. För att minska stressen får studenterna idag modelltexter från tidigare terminer som kan ge dem förebilder och visa var kravnivåerna ligger. För att hushålla med lärarnas arbetstid får studenterna skriftliga kommentarer enbart på sin första textversion, som sedan följs upp av ett summativt betyg efter skalan U-VG vid examinationen. Stressnivån har minskat för varje ny termin som delkursen har gått.

\section{FRAMGÅNGSFAKTORER}

Över de tre terminerna har momentet blivit väl integrerat i delkursen, vilket antagligen är den viktigaste anledningen till att det lever kvar. Integreringen har huvudsakligen gjorts av Anders i egenskap av delkursansvarig lärare, med stöd från särskilt Studieverkstan och Biblioteket. Det krävs uppenbarligen ett stort engagemang, men också mandat att genomföra förändringar. Mandatet kan, som i detta fall, vara uttalat från ledningen, men det kan också komma genom kontinuitet ifall en lärare är ansvarig för en delkurs under flera terminer i följd och därmed har möjlighet att driva förändringar. Therese och Hedda, som alltså representerat Biblioteket och den högskolepedagogiska enheten här, kan också konstatera att Anders på många sätt gjort momentet till sitt eget, då han t.ex. förde över formaliakrav till andra uppgifter inom delkursen och skapade ett lärandemål för akademiskt skrivande. En annan framgångsfaktor i sammanhanget kan vara att Anders deltagit i en högskolepedagogisk diskussionscirkel med andra lärare på högskolan. Cirkeln har fungerat som en plattform för att läsa och diskutera centrala texter om studenters akademiska skrivande och syftet har varit att stötta lärarna $\mathrm{i}$ deras arbete.

\section{NÅGRA RÅD PÅ VÄGEN}

Vi som representerar den högskolepedagogiska enheten och Biblioteket vill avsluta med några råd på vägen för den som arbetar vid liknande enheter och som vill fördjupa samarbetet med utbildningar och lärare vid lärosätet. För det första är det en stor fördel att satsningen har ett övergripande högskolepedagogiskt syfte och ett uttalat mål om att momentet ska lämnas över till utbildningen. Momentet blir då inte bara en fråga om en viss studentgrupps akademiska litteracitet, utan ett exempel på hur lärare kan utveckla studenternas akademiska skrivande i den ordinarie undervisningen. För det andra är det tydligt att momentet måste omges av vissa dokument som kan bära information över flera terminer, så att momentet inte faller om t.ex. lärare byts ut. Kursplaner, studiemanualer och lärarhandledningar är sådana dokument, men det är också viktigt att uppgiftsformuleringar, betygskriterier, powerpoint-bilder och responsmallar är självinstruerande. För det tredje är det viktigt att alla involverade förstår varför momentet ligger inom delkursen - och inte köps in från Studieverkstan och Biblioteket - samt att lärarna får se att just deras arbete med studenternas skrivande ger fördelar. På delkursen Polisen i samhället, t.ex., har genomströmningen ökat och lärarlaget ser förbättringsresultat på så sätt att de behöver hantera färre kompletteringar.

Vad har då sammanfattningsvis fått momentet att leva kvar i programmet? Vi tror att följande punkter har haft särskild betydelse: 
- Målet med samarbetet är högskolepedagogiskt.

- Utbildningens administrativa ledning ger lärarna ett formellt uppdrag samt stöd och uppmuntran.

- Representanter för satsningen träffar alla lärare på utbildningen i början av samarbetet och inför överlämningen. Temat för träffarna är akademisk litteracitet respektive upplägget av momentet med studenterna.

- En engagerad och drivande delkursansvarig, som är beredd att göra momentet till "sitt eget".

- Delkursansvarig lägger till ett lärandemål i kursplanen med fokus på akademiskt skrivande. Studenterna får modelltexter från tidigare år och alla uppgifter i delkursen formuleras så att de ställer samma formkrav.

- Studieverkstan och Biblioteket stöttar delkursansvarig i formulerandet av uppgift, responsmall och betygskriterier.

- Delkursansvarig fördjupar sina kunskaper om studenters akademiska skrivande, t.ex. genom att delta i en högskolepedagogisk diskussionscirkel.

\section{FÖRFATTARPRESENTATION}

Hedda Söderlundh är fil.dr i nordiska språk och lektor i svenska vid Södertörns högskola. I det samarbete som beskrivs i texten representerar hon högskolans enhet för högskolepedagogik och bildning, där hon framför allt träffar lärare som på olika sätt vill stötta studenternas akademiska litteracitetsutveckling. T.ex. har hon lett en diskussionscirkel för lärare kring temat.

Therese Lind är bibliotekarie vid Södertörns högskolebibliotek och arbetar huvudsakligen med att undervisa och handleda studenter i kritisk informationssökning. I rollen som pedagogisk samordnare på biblioteket samarbetar hon även med Utvecklingsenheten för högskolepedagogik och bildning och Studieverkstan kring högskolepedagogiska frågor med fokus på studenters akademiska skrivande.

Anders Nordström är fil.dr i statsvetenskap, lektor och verksamhetsutvecklare på Polisutbildningen på Södertörns Högskola och har varit verksam på utbildningen sedan den startade på Södertörn 20I5. Han är delkursansvarig för Polisutbildningens inledande delkurs, Polisen i samhället, där det skrivande som beskrivs i texten ingår.

\section{REFERENSER}

Eklund Heinonen, M. \& Sköldvall, K. (20I5). Nu har vi ett gemensamt språk: Om ämnesintegrerad undervisning i akademiskt skrivande. Högre utbildning, 5(2), 133-138.

Lea, M.R. \& Street, B. (1998). Student Writing in Higher education. Studies in Higher Education, 23(2), I57-I72.

Lennartson-Hokkanen, I. (2016). Organisation, attityder, lärandepotential: ett skrivpedagogiskt samarbete mellan en akademisk utbildning och en språkverkstad (Doktorsavhandling, Stockholms universitet, Institutionen för svenska och flerspråkighet).

Saunders, L. (20I2). Faculty Perspectives on Information Literacy as a Student Learning Outcome. The Journal of Academic Librarianship, 38(4), 226-236.

Sköldvall, K., Rising, C. \& Danielsson, M. (2017). "Får man säga att det känns hopplöst?": Polisstudenter möter det akademiska skrivandet. I: A. Malmbjer (Red.), Studenters skrivande i humaniora och sambällsvetenskap (215-236). Huddinge: Södertörns högskola. 